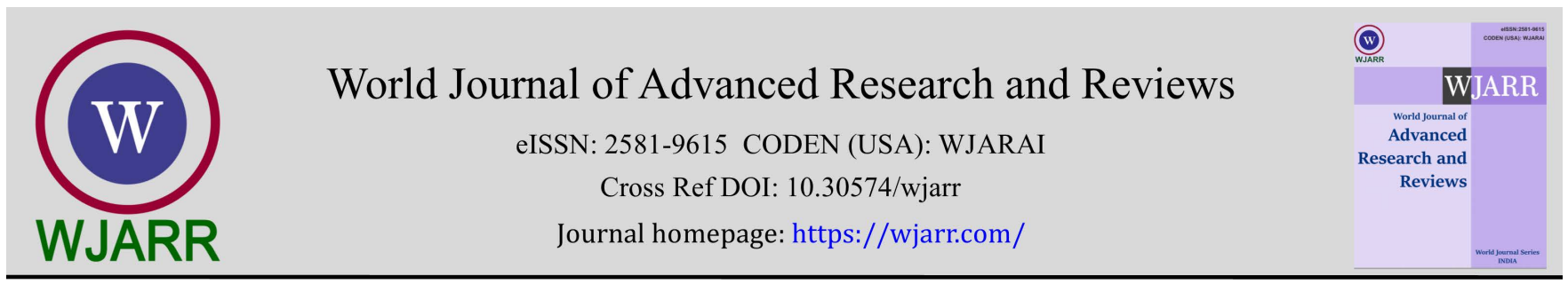

(REVIEW ARTICLE)

\title{
A review of research in soil fertility management and plant nutrition of cashew (Anacardium occidentale L.) in Nigeria
}

\author{
Habibu Aminu *, Isiyaku Alhaji Musa, Hamidu Muhammed Askira and Saminu Hamisu Aliyu \\ Cocoa Research Institute of Nigeria, P.M.B. 5244, Ibadan, Oyo State, Nigeria.
}

World Journal of Advanced Research and Reviews, 2021, 11(03), 160-167

Publication history: Received on 06 August 2021; revised on 14 September 2021; accepted on 16 September 2021

Article DOI: https://doi.org/10.30574/wjarr.2021.11.3.0434

\begin{abstract}
The paper reviewed researches conducted in soil fertility management and plant nutrition of cashew in Nigeria. It also examines the history and importance of cashew to the Nigerian economy. The paper highlights ways of improving soil fertility and plant nutrition in cashew cultivation through the use of different sources of organic fertilizers which are cheap and readily available for the farmers rather than total dependence on costly chemical fertilizers. Also highlighted, are some recommended rates of organic and inorganic fertilizers for the cultivation of cashew from research findings. The paper also discussed status of Nigeria cashew production, research efforts, achievements, constraints, and areas of possible improvement in relation to soil fertility management and plant nutrition.
\end{abstract}

Keywords: Research; Soil fertility management; Plant nutrition; Cashew; Nigeria

\section{Introduction}

Cashew is the common name for a tropical and subtropical evergreen tree, Anacardium occidentale $\mathrm{L}$., in the flowering plant family Anacardiaceae. It is also the name for the commercially important kidney-shaped, nut like seed of this plant, which is edible when roasted or cooked [1]. The plant is a native of Tropical Central and South America, notably North Eastern Brazil, from where the Portuguese explorers introduced it into Nigeria in the 15th/16th century [2- 4]. The history of cashew in Nigeria dated back to 15th century. Then, it was mainly used in afforestation schemes for the control of erosion in the former Eastern Nigeria. However, the commercial cashew plantations started in Nigeria in the early 1950s with the establishment of first commercial plantations at Oghe, Oji and Mbala by the defunct Eastern Nigeria Development Corporation (ENDC) and Iwo, Eruwa and Upper Ogun by the defunct Western Nigeria Development Corporation (WNDC). From these locations, the planting of the crop spread to other parts of Nigeria particularly the Central and Northern States of Nigeria [5]. Research on cashew production and its uses started at the Cocoa Research Institute of Nigeria (CRIN), Ibadan in 1971. The introduction of Brazilian cashew biotype with improved and desirable nut and kernel quality characteristics by CRIN has further increased the crops spread and popularity in Nigeria [6].The commodity of commercial importance is the nut, which contains $47 \%$ fat, $21 \%$ protein and $22 \%$ carbohydrate. It also contains vitamins, especially thiamine [7]. Cashew nut proteins are complete, having all the essential amino acids and a kilogramme of the nut yields about 6000 calories compared to 3600 calories from cereals, 1800 calories from meat and 650 calories from fresh citrus fruit [8]. The cashew nut shell liquid (CNSL) is used widely in brake linings of motor vehicles, paints, varnishes and laminated products [9]. Plant growth is the result of a complex process whereby the plant synthesizes solar energy, carbondioxide, water, and nutrients from the soil. In all, between 21 and 24 elements are necessary for plant growth. The primary nutrients for plant growth are nitrogen, phosphorus, and potassium (known collectively as NPK). When insufficient, these primary nutrients are most often responsible for limiting crop growth. Nitrogen, the most intensively used element, is available in virtually unlimited quantities in the atmosphere and is continually recycled among plants, soil, water, and air. However, it is often unavailable in the correct form for proper

\footnotetext{
* Corresponding author: Habibu Aminu

Cocoa Research Institute of Nigeria, P.M.B. 5244, Ibadan, Oyo State, Nigeria.
} 
absorption and synthesis by the plant. In addition to the primary nutrients, less intensively used secondary nutrients (sulfur, calcium, and magnesium) are necessary as well. A number of micronutrients such as chlorine, iron, manganese, zinc, copper, boron, and molybdenum also influence plant growth. These micronutrients are required in small amounts (ranging from a few grams to a few hundred grams per hectare) for the proper functioning of plant metabolism. The absolute or relative absence of any of these nutrients can hamper plant growth; alternatively, too high a concentration can be toxic to the plant or to humans. The capacity of soils to be productive depends on more than just plant nutrients. The physical, biological, and chemical characteristics of a soil for example its organic matter content, acidity, texture, depth, and water-retention capacity all influence fertility. Because these attributes differ among soils, soils differ in their quality. Plants need a given quantity and mix of nutrients to flourish. The higher the yield, the greater the nutrient requirement. A shortage of one or more nutrients can inhibit or stunt plant growth. But excess nutrients, especially those provided by inorganic fertilizers, can be wasteful, costly, and, in some instances, harmful to the environment [10].

A farmer is motivated towards farming when the yearly harvest is high and for the harvest to be high, the soil must be well maintained and conserved. Nigeria as a whole is faced with a problem of soil management and in particular to the farmers cultivating these commodity crop (cashew) which is faced with a problem of poor crop yield due to the inability of carrying out soil management practices for maintaining the fertility of the soil. So, any measure taken to manage the soil for its fertility will go a long way in improving the fertility of the soil for the growth of crops and general wellbeing of the farmers. Considering the significance of these commodity crops in the livelihood and economy of the nation, a concerted research effort on improving there yield and increasing production per land area is key. While this may change the place of Nigeria productivity status globally, it will also impact on local processing and consumption. The current status of Nigeria cashew production, research efforts, achievements, constraints, and areas of possible improvement in relation to soil fertility management and plant nutrition is hereby discussed.

\section{Botany and Taxonomy of Cashew}

Cashew (Anacardium occidentale L.) belongs to the order Sapindales, family Anacardiaceae and genus Anacardium. The Anacardiaceae family consists of about 75 genera and 700 species [11]. Botanically, the Anacardiaceae includes primarily trees and shrubs with resin canals, resinous bark and clear to milky exudates. The trees or shrubs have alternate, often trifoliate or pinnate leaves. Flowers are generally not highly conspicuous and can either be unisexual or bisexual. Only one carpel matures, forming a drupe (a fleshy fruit with a stoney seed). In some cases, the drupy fruits produce an irritant called urushiol. Cashew is related to Mango (Magnifera indica L), Pistachio (Pistacia vera L), Poison ivy (Toxicodendron rydbergii) and Poison oak (Toxicodendron diversilobum) which are also in the Anacardiaceae family. In the genus Anacardium, nine species are identified under numerical taxonomy [12]. These include Anacardium corymbosum Barb.Rodr.p, Anacardium excelsum L., Anacardium giganteum (Bertero \& Balb. ex Kunth) Skeels,Anacardium humile Hance ex Engl., Anacardium microcarpum A.St.-Hil.,,ppp, Anacardium nanum A.St.-Hil., Anacardium negrense Pires \& Froes, Anacardium occidentale L. and Anacardium spruceanum Benth. ex Engl. Of all, only cashew (Anacardium occidentale) is of economic importance because of its edible apple and nutritious kernel [13].

\section{Origin and Distribution}

Cashew (A. occidentale L.) is native to Latin America and has a primary center of diversity in Amazonia, and a secondary one in the Planalto of Brazil. Natural occurrence of cashew has been reported from Mexico to Peru, and in the West Indies. It was one of the first fruit trees from the New World to be widely distributed throughout the tropics by the early Portuguese and Spanish adventurers [14]. Portuguese explorers introduced it to the tropics of Asia and Africa from where it spread into other parts of the world. At present, cashew is produced in 32 countries of the world with sufficient warm and humid climate. The main producers however are Brazil, Benin Republic, Cote dilvore, Ghana, Guinea Bissau, India, Mozambique, Nigeria, Philippines, Srilanka, Tanzania and Vietnam.

\section{Cashew in Nigeria}

Cashew was introduced into Nigeria between 15 and 16 centuries by the Portuguese explorers. The plant was then, purposefully for erosion control and afforestation schemes of the defunct Eastern Nigeria. Cashew became a popular crop in 1953, when planted on a large scale principally for the nuts, afforestation and erosion prevention programmes in the escarpment areas of Udi, Mbala, Oghe, Oji, Isuochi and Kingie in Eastern Nigeria by the defunct Eastern Nigeria Development Corporation [15,16]. In Western Nigeria, the first planting of cashew started in $16^{\text {th }}$ century at Agege in Lagos. The commercial cultivation actually started in 1950s at Iwo, Eruwa and Upper Ogun in the defunct Western Nigeria by the then Western Nigeria Development Corporation (WNDC) [17]. 
Cashew was thereafter introduced into Northern Nigeria from the Eastern and Western Nigeria. These cashew nuts were mainly of the medium nut-size biotype, which according to IS0-6477 standard fall within the W320 category. This cashew biotype therefore constitutes the landrace of cashew in the Nigerian cashew plantations. This biotype, which was an introduction from Asian continent attracts low premium in the International market. However, with the recent introductions of the Brazilian cashew biotype (jumbo nut-size), by Cocoa Research Institute of Nigeria (CRIN), which is now being grown by cashew farmers, the cultivation of the crop is rapidly spreading to all agro-ecologies of Nigeria $[18,19]$.

Today, cashew cultivation has spread to almost all the states of Nigeria with increased processing, shipping and exporting activities. The major Cashew growing areas in the different parts of Nigeria in the order of the level of productivity with respect to the different regions of the country are: Enugu, Abia, Imo, Anambra, Ebonyi and Cross River States in the east and southern part, Oyo, Osun, Ondo, Ekiti and Ogun States in the western part, Kwara, Kogi, Nassarawa, Benue, Taraba, Niger, Federal Capital Territory (Abuja), Kaduna and Plateau in North Central Nigeria and Sokoto and Kebbi States in the North western of the country $[20,21]$.

\section{Research Efforts}

As a preliminary effort to commence organic cashew farming in Nigeria, a study to assess the growth performance of cashew seedlings was conducted in two consecutive trials in the greenhouse at Cocoa Research Institute of Nigeria, Ibadan using four organic nutrient sources namely cow dung, poultry droppings, cocoa pod husk and kola pod husk compared with NPK (15:15:15) and control (without fertilizer). Results from this trial shows that the organic fertilizers were superior to NPK while organic fertilizers of animal origin were superior to those of plant origin [22].

Rajamanickam et al. [23] reported that the soil application of recommended dose of fertilizers along with soil application of micronutrients (NPK - 280:160:240 g NPK/tree + Ferrous sulphate - 200g /plant) registered the highest values in the traits like nut weight (59.11 g), yield per tree $\left(11.14 \mathrm{~kg}\right.$ ), estimated yield per ha $\left(2.25 \mathrm{t} \mathrm{ha}^{-1}\right)$ and $\mathrm{B}: \mathrm{C}$ ratio (2.41). The results of the findings of a study carried out to evaluate the nutrient dynamics in soil, cashew and nuts in Kogi State which is one of the major cashews producing states in Nigeria shows a low clay and organic matter content of the soils which had a negative influence on the soils fertility status thereby reflecting in the minerals and nutrient contents of the foliage and nuts. Therefore, it was recommended by the scientists that regular fertilizer and compost application should be done on the farms to replenish the lost nutrients and improve the water holding capacity of the soil [24]. The findings of their study will form the basis for recommending fertilizer application to increase cashew production and yield in Kogi state.

Hammed et al. [25] reported from their study on the growth and nutrient uptake of cashew seedlings that the nitrogen content of these seedlings was highest followed by calcium content while phosphorus content was lowest. While cashew seedlings raised from jumbo nut-size had the highest uptake of N, P, K, Ca and Mg followed by seedlings raised medium and madras nut sizes in that order. This implies that, in the production of the crops seedlings using jumbo nut-size, there should be an appropriate nutrient supplementation arrangement in order to sustain the higher growth vigour of the seedlings in the nursery. In tree crop culture, higher plant vigour is a veritable selection determinant of transplant able seedlings in order to have appreciable survival rates of the seedlings after transplanting into the field. Although cashew flourishes in soils where most other crops do not [26] it does perform better with nutritional assistance. Cashew responded well to fertilizer application, especially during the vegetative growing period. The use of organic fertilizer amended with phosphate fertilizer and arbuscular mycorrhizal fungi (AMF) inoculation were found to have positive influence on the growth of cashew and the chemical properties of the soil. Nigerian Sokoto rock phosphate was discovered a viable option to single super phosphate for cashew production [27,28]. Recent work by Adewale et al. [29] also revealed that the trend of growth and development of cashew genotypes differed in response to varied combination of soil nutrients. The effect of vamcycorrhiza inoculation on cashew seedling height and dry matter yield was significantly higher than those without inoculation. The interaction effect of phosphate fertilizers (SRP and SSP) with vamycorrhiza significantly enhanced both the dry matter yield and seedling height [30]. The use of inorganic fertilizers for cashew nutrition had been established [31,32]. Phosphorus plays an indispensable role as a universal fuel for all biochemical work in living cell and in particular root development which is important to crop establishment in the field. Application of P-chemical fertilizers on a long-term basis lead to reduction in $\mathrm{pH}$ and exchangeable bases and thus reduces crop productivity. The use of organic fertilizer to grow tree crops has been reported the application of compost, which improved the biological activity of the soil and has a direct impact on the sustainability of soil health [33, 34]. Ibiremo et al. [35] reported that the growth of cashew seedlings was greatly improved as a result of the application of organic fertilizer, phosphate fertilizer and Arbuscular mycorrhizal inoculation, while the influence of single super phosphate was not superior as sokoto rock phosphate in all the parameters considered. From the results of an experiment carried out in the greenhouse at Cocoa Research Institute of Nigeria (CRIN) headquarters Ibadan, 
organomineral fertilizer (Pacesetter A and Pacesetter B) enhanced cashew seedlings performance irrespective of sizes better than the inorganic fertilizer [36]. Organic fertilizer amended with phosphate fertilizer and Arbuscular mycorrhizal inoculation has positive influence on the growth of cashew and the chemical properties of the soil in the greenhouse of Cocoa Research Institute of Nigeria Ibadan in 2007/2008 seedling production [37].

Research conducted in CRIN Ibadan on the influence of organic manure and biochar on cashew seedling performance, soil properties and status. The results obtained from this study shows that the application of biochar, and compost manure solely or in combinations have significant agronomic benefit to the soil. In this research, the impacts of biochar include: modification of the soil physical and chemical properties, enhancement of cashew seedling vegetative growth parameters and improved nutrient uptake. And the presence of entomopathogen and bio-control agent indicates crop protection advantage of this bio-fertilizer [38] Fertilizer application has been used to control plant diseases of vegetables and crops. Woltz and Jones [39] reported that tomato studies showed better fusarium wilt control when nitrogen was used in soil with high $\mathrm{pH}$. The nitrate nitrogen from also produced the lowest levels of fusarium or chrysanthemum, king asters and carnations [40]. The first available report on the use of fertilizers to reduce disease infection of cashew in Nigeria was written by Adejumo [41]. Adequate crop nutrition makes plants to be more tolerant or resistant to disease, while the nutrient status of the soil, the particular fertilizers and amendments can have significant impact on the pathogen's environment [42]. Regular application of major plant nutrients (N P K) is beneficial for healthy trees and increased yields in cashew $[43,44]$.

\section{Cashew Production and Research Constraints}

Various constraints are militating against the production, marketing and processing of cashew fruits in Nigeria. Cashew producers have called on the government to arrest the increasing transport of the nuts into neighbouring like Togo, Benin and Cameroon from where they are exported to Europe and U.S.A[45]. Akinwale and Ayodele [46] identified the following constraints of cashew production in Nigeria; land acquisition (about $60 \%$ of Nigeria cashew nut production is attributed to small-scale farmers who manage between 2-4 ha of cashew )is, unavailability of labour, lack of processing technology, high cost of production, unstable market system, low soil fertility, high interest rate, low funding, inadequate infrastructural facilities such as rural roads, electricity, water supply and poor exit services.

The major constraints in soil fertility management and plant nutrition research of Cashew in Cocoa Research Institute of Nigeria and other research institutes across Africa can be attributed to the following reasons:

- Inadequate funding of research investigations, erratic electricity power supply and under equipped soil science laboratories and screen houses.

- Very few scientists and technical officers with specialization in soil and plant nutrition are employed across research centers.

- Absolute equipments and tools used in carrying out research activities

- Dearth of vehicles to ease transportation to plantations for research investigations

- Lack of training and re-training of research officers, technologists, field superintendent and statistician on modern experimental procedures in soil and plant nutrition.

\section{Cashew Research Potentials and Prospects in Soil Fertility Management and plant Nutrition}

Although, cashew grows well on wide range of soils irrespective of their textural, structural and fertility status, its survival and establishment however are often affected by poor soils. It has been reported that cashew requires fertile soils and need soil fertility amendment like other tree crops in order to produce nuts and apples economically. In Nigeria, the quest to optimally increased cashew crop yield with fertilizer use has not been attained as a result of lack of adequate fertilizer recommendation because fertilizer usage is mostly based on blanket application, while soil testing programme does not take into account the amount of nutrient being fixed and lost by the soils [47]. There is a need for precise research to be conducted on fertilizers rates so that a recommendation will be made to the farmers. Proper and holistic soil testing should be done on the soils in order to ascertain their nutrient requirements and deficiencies.

Akanbi et al. [48] reported from their experiment conducted in a greenhouse at Cocoa Research Institute of Nigeria, Ibadan that optimal and sustainable growth performance of cashew seedlings can be attained by the use of organic $f$ ertilizers especially those of poultry dung manure and Cocoa pod husk ash which are cheap and readily available for the farmers rather than total dependence on costly and scarce chemical fertilizers. Their research needs to be continued in subsequent years in the field and in different cashew growing states in order to attain maximum rates of the organic fertilizers (ie PDM and CPHA) required at different locations. Long-time research can be conducted to find out an 
appropriate mixture of the different rates of inorganic fertilizers (N,P,K, and Arbuscular mycorrhizal inoculation,) organomineral fertilizers and Organic fertilizer (biochar, animal, plant manures and green manures) and Arbuscular mycorrhizal inoculation.

\section{Organic cashew}

Cashew is grown without the use of agro-chemicals in Nigeria, the organic nature of Nigeria cashew is currently a pride. The use of chemicals is mostly on experimental fields. Efforts must be made to uphold the status by cultivating Cashew organically ever since the depleting soil fertility attained a serious concern with the practice of high-density planting coupled with heavy use of chemical fertilizers in some cases. Organic cashew cultivation is often considered amongst one of the sustainable agricultural practices; if used appropriately, it promises to offer rich dividends on a long-term basis. This will in turn improve nitrogen use efficiency, reduce nitrate pollution, contamination due to by-products of various chemical pesticides in use, and continued gradual loss of soil organic matter which have always been the major core issues in organic farming [49]. Promotion of certified organic cashews will improve the export value of cashew products and open new markets to Nigerian exporters. Organic cashew snack products are in strong demand, with sales increasing at over $80 \%$ per year in the US market.

\section{Conclusion}

Although, Nigeria has a cashew cultivation history of more than four hundred years, research and development into its production, processing and marketing started some forty years ago. Over those years, there have been intensified efforts to boost cashew research for improved production. Increasing demand for cashew nuts as raw materials in the confectionery and industrial trade in Europe has stimulated cashew exportation from Nigeria. The less health risk from the consumption of cashew is one of the attracting reasons for increasing consumption and demand. The protein in cashew is abundant ( $>20 \%$ ) and of a high quality probably more than in meat or fish [50,51]. The soluble sugar in the kernel is almost as low as 1\%; hence, cashew nut consumers are therefore privileged to get a sweet taste without having to worry about excess calories [52]. West Africa is now the major supplier of raw materials to the Indian processing sector. Few among the list of possible ways to increasing cashew production in Nigeria are: proper soil fertility management and plant nutrition through the use of organic fertilizers which are cheap and readily available for the farmers rather than total dependence on costly and scarce chemical fertilizers, precise research needs to be conducted on fertilizers rates so that a recommendation will be made to the farmers. Proper and holistic soil testing should be done on the soils in order to ascertain there nutrient requirements and deficiencies. Long-time research can be conducted to find out an appropriate mixture of the different rates of inorganic and organic fertilizers.

\section{Compliance with ethical standards}

\section{Acknowledgments}

Special thanks to my co-authors for their input toward the success of this paper.

\section{Disclosure of conflict of interest}

There is no conflict of interest in this publication.

\section{References}

[1] New World Encyclopaedia.Cashew from New World Availableonline@http://www.newworldencyclopedia.org/p/index.php?titleCashew\&oldid=678619; 2008.

[2] Ohler JG. Cashew Growing. Tropical Abstracts (The Netherlands).1967; 22(1): 1-9.

[3] Ohler JG. Cashew. (Koninklijk Instituut Voo de Tropen:Amsterdam, Netherlands). 1979a; 260.

[4] Venkataramah TM. Cashew nut production and processing - Nigeria agronomic aspect of cashew nut production. Unpublished paper submitted to CRIN. 1976; 39.

[5] Togun A. A review of the prospect of cashew industry. 1977; 39.

[6] Hammed LA, Adedeji AR, Asogwa EU, Ibiremo OS. Constraints to cashew production in Nigeria. A paper presented at the cashew stake-holders meeting organised by the African Cashew Alliance (ACA) helt at IITA, Ibadan, Nigeria. 26 January 2007; 12. 
[7] Nandi BK. Cashew nut nutritional aspects. In: Integrated Production Practices of Cashew in Asia. Edited by Papademetriou M.K. Herath, E.M. FAO/UN. File://A:\FAO Document Repositoryfiles $\backslash$ AC45/EOB.HT M. $1998 ; 8$.

[8] Nambiar MC, Rao B Thankamma EVV, Pillai PK. Cashew. In:Bose T.K. Mitra, S.K. (Eds) Fruits: Tropical and Subtropical, Naya Prakash, Calculta. 1990; 386-419.

[9] Murthy BGK, Sivasamban MA. Recent trends in CNSL utilization. Cashew Research and development: Proceedings of the International Cashew Symposium, Cochin, Kerala, India. March 12-15, 1985. 1985; 201-207.

[10] Peter Gruhn, Francesco Goletti, Montague Yudelman. Integrated Nutrient Management, Soil Fertility, and Sustainable Agriculture: Current Issues and Future Challenges. Food, Agriculture and the Environment Discussion Paper 32. International Food Policy Research Institute, 2033 K Street, N.W. Washington, D.C. 20006 U.S.A. September 2000.

[11] Nakasone HY, Paull RE. Tropical Fruits. CAB International, Oxford, UK. 1998.

[12] Mitchell JD, Mori SA.The Cashew and Its Relatives (Anacardium:Anacardiaceae), New York Botanical Garden, New York. 1987.

[13] Adeigbe 00, Olasupo FO, Adewale BD, Muyiwa AA. A review on cashew research and production in Nigeria in the last four decades.Scientific Research and Essay. 15 March, 2015; 10(5): 196-209.

[14] Deckers J, Driessen P, Nachtergaele F, Spaargaren O. World Reference Base for Soil Resources - in a nutshell. European Soil Bureau - Research Report No. 7. 2001; 173-181.

[15] Togun A, Igbokwe AD. Biology and control of pests and diseases of cashew (Anacardium Occidentale L.). A paper presented at symposium to mark the 21st anniversary of the establishment of Cocoa Research Institute of Nigeria, Ibadan. 1985.

[16] Akinwale SA, Esan EB. Advances in cashew breeding in Nigeria. In: Progress in Tree Crop Research, 2nd edn. Cocoa Research Institute of Nigeria (CRIN), Ibadan, Nigeria. 1989; 166-174.

[17] Sanwo JO, Kuti BO, Osudolire M. Germplasm collection. 1972/73 Cocoa Research Institute of Nigeria (CRIN) Annual Report.1972.

[18] Falade JA. Soils of cashew growing areas of Nigeria. East Africa Journal of Agriculture. 1978; 2: 31-36.

[19] Topper CP, Caligari PDS, Camara M, Diaora S, Djaha A, Coulibay F, Asante AK, Boamah A, Ayodele EA, Adebola PO. West African Regional Cashew Survey Report (Guinea, Guinea Bissau, Cote D' Ivore, Ghana and Nigeria). Sustainable Tree Crop Programme (STCP) and Biohybrids Agrisystem Ltd. U.K. 2001; 1: 110.

[20] Ezeagu W. Assessment of the situation and development prospects for the cashew nut sector. A report of the International Trade Center UNCTAD/WTO (ITC). 2002.

[21] Chemonics International Inc. Subsector Assessment of the Nigerian Cashew. The United States Agency for International Development (USAID)-Nigeria RAISE IQC, Contract no. PCE-I-00-99-00003-00 Task Order No. 812 Industry.2002; $1-44$.

[22] Ipimorotimi RR and Akanbi OSO. Comparison of organic nutrients sources with NPK for cashew seedlings growth towards organic cashew farming in Nigeria. International Journal of Plant and Soil Science. 2015; 4(2): $185-195$.

[23] Rajamanickam C, Rathinasamy A, Indirani R, Anbarasu M. Effects of soil application of micronutrients in cashew (Anacardium Occidentale L.). International Journal of Current Microbiology and Applied Sciences. 2020; 9(3): 2661-2666.

[24] Aikpokpodion PE, Uloko B, Edibo G. Nutrient dynamics in soil and cashew (Anacardium Occidentale L.) leaf and kernel in Kogi State, Nigeria. Journal of Applied Biosciences. 2009; 25:1573-1578.

[25] Hammed LA, Laval BA, Kolapo, KA. Growth and nutrient uptake of cashew seedlings as affected by nut-size in the nursery. African Journal of Agricultural Research. 2011; 6(17): 3962-3971.

[26] Ohler JG. Cashew Growing: Tropical Abstracts. Cashew Dept. Agric.Res., Royal Tropical Institute Press, Amsterdam. 1979b.

[27] Ibiremo OS. Effect of Organic Fertilizer Fortified with Phosphate Fertilizers and Arbuscular Mycorrhizal Fungi Inoculation on the Growth of Cashew in Two Ecologies in Nigeria. J. Agri. Sci. 2010; 1(2):101-107. 
[28] Ibiremo OS, Ogunlade MO, Oyetunji OJ, Adewale BD. Dry matter yield and nutrient uptake of cashew seedlings as influenced by arbuscular mycorrhizal inoculation, organic and inorganic fertilizers in two soils in Nigeria. ARPN J. Agric. Bio. Sci. 2012; 7(3): 1990-6145.

[29] Adewale BD, Ibiremo OS, Odoh NC, Adeyemi EA. Genetic estimates and trend analysis of some growth parameters of cashew (Anacardium occidentale L.) as influenced by nine nutrient combinations. J. Agric. Biotechnol. Sus. Dev. 2013; 5: 6-11.

[30] Ibiremo OS, Ogunlade MO, Iloyanomon CI, Yabagi AA. Response of cashew seedlings from different sizes to phosphate fertilizers and vamycorrhizal inoculation. CRIN Annual Report. 2003; 51-52.

[31] Lefebvre A. Preliminary information on manuring the cashew-nut. Fruits. 1970; 25(9): 621-628.

[32] Owaiye AR, Olunloyo OA. The effect of NPK fertilizer combinations on incidence of inflorescence blight disease of cashew at Ochaja. Annual Report of Cocoa Research Institute of Nigeria. 1990.

[33] Aisueni NO, Malomo RA. Bioavailability Potentials of P in soils supporting oil palm (Elaeis guineensis, jacq). In the Nigerian Journal of Tree Crop Research. 2000; 4(1): 62-72.

[34] Nagaraj TS. Discussion: Characteristics water contents of fine grained soil-water system. Geotechnique. 2000; 50(3): 305-306.

[35] Ibiremo OS, Ogunlade MO, Iloyanomon CL. Response of cashew seedlings to organic fertilizers and Amfuji inoculation in a versic-ochraqualf in Nigeria. CRIN Annual Report. 2004; 56-57.

[36] Adebowale AA, Sanni LO, Onitilo MO. Chemical composition and pasting properties of tapioca grit from different cassava varieties and roasting method. African Journal of Food Science. 2008; 2: 77-82.

[37] Iloyanomon CL, Ibiremo OS, Adeyemi E. Growth and Yield of Cashew as Influenced by Leguminous Cover Crops. CRIN Annual Report. 2012; 230-231.

[38] Nduka BA, Ogunlade MO, Adeniyi DO, Oyewusi IK, Ugioro O, Mohammed I. The influence of organic manure and biochar on cashew seedling performance, soil properties and status. Agricultural sciences. 2019; 10: 110-120.

[39] Woltz SS, Ebgelhard AW. Fusarium wilt of chrysanthemum: effect of nitrogen source and lime on disease development. Phytopathol.1973; 63: 155-157.

[40] Woltz SS, Jones JP. Tomato Fusarium wilt control by adjustments in soil fertility. Proceedings of Florida State Horticultural Society.1973; 86: 157-159.

[41] Adejumo TO. Effects of NPK fertilization on Yield and inflorescence blight of cashew. Journal of Agric Biotechnology and Sustainable Development. 2010; 2(5): 66-70.

[42] National Center for Appropriate Technology, (NCAT).Sustainable Management of Soil borne Plant Diseases. Preston Sullivan (ed.). Soil Systems Guide. Slot 131, Version 071604. http://www.attra.org/attrapub/soilborne.html. 2004; 173: 16.

[43] Fernandopulle MN. Fertilizer use in cashew. Cashew Bull. 2000; 3(1): 1-6.

[44] FAO, Azam-Ali SH, Judge EC.Small-scale cashew nut processing. (ed) Publishing Management Service, Information Division, FAO, Viale delle Terme di Caracalla, 00100 Rome, Italy.FAO. 2004.

[45] Igwe CA. Free oxide distribution of Niger floodplain soils in relation to their total and available phosphorus. Paper presented at the 27th Annual Conference of Soil Science Society of Nigeria, University of Calabar, November 5-9, 2001.

[46] Akinwale TO, Ayodele FA. Production Constraints. Quarterly Nigeria's first magazine journal. $1999 ;$ 2(9): $45-47$.

[47] Ogunlade I, Illugbiyin A, Osasona AI. A comparative study of the proximate composition, anti-nutrient composition and functional properties of Pachira glabra and Afzelia Africana seed flours. African Journal of Food Science. 2011; 5(1): 32-35.

[48] Akanbi OSO, Famaye AO, Ojeniyi SO, Nduka BA, Taiwo N, Olasupo FO, Azeez OM, Edibo GO, Gbemisola DO. Growth response of cashew seedlings to applied organic fertilizers of animal and plant origin on a degraded soil in Ibadan, South-West, Nigeria. International Research Journal of Agricultural Science and Soil Science. 2013; 3(3): 93-98.

[49] Ferguson BK. Stormwater infiltration. CRC Press, Boca Raton, Florida. Dodge, editor. Proceedings of the international large river symposium. Special Publication Canadian Journal of Fisheries and Aquatic Sciences.1994; 106. 
[50] Soman VV, William LS, Charles AL. Modelling soil moisture using passive remote sensing. Proceedings of Spie 3222, Earth Surface Remote Sensing. 30 December 1997.

[51] Adavi RD. Molecular diversity and phenotyping of selected cashew genotypes of Goa and physiological response of cv. GOA-1 to insitu moisture conservation. A PhD Thesis submitted to the University of Agricultural Sciences, Dharwad.2008; 121.

[52] Sasi Varma K. Nutritional values of cashew nut. In: Singh HP, Balasubramanian, P.P. Venkatesh, N.H (eds) Indian Cashew Industry, Directorate of Cashew nut and Cocoa Development. 2002; 124-129. 